\title{
The Deep Meaning of Symbolism Significance in Men in the Sun
}

\author{
Omer Elsheikh Hago Elmahdi \\ Open University of the Sudan, Sudan
}

\author{
Abdulrahman Mokbel Mahyoub Hezam \\ Department of English, Faculty of Arts, Taiz University, Yemen; \\ Department of Languages and Translation, Faculty of Science and Arts, Taibah University, Al-Ula, Saudi Arabia
}

\begin{abstract}
The novel of MEN IN THE SUN by Ghassan Kanafani reflects the Palestinian cause, the 1948 catastrophe and its impact on the Palestinian people through Palestinian men of different generations who tell their story in a wonderful symbolic way. The novelist reflected the issue through the characters, as each character in the novel symbolizes a certain personality of his people. The story is the story of three men who decide to emigrate from Palestine to Kuwait illegally for their desire to improve their living conditions. The novel ends with the death of the three men suffocating for fear of beating the walls of the tank. This study is an attempt to examine the symbolism in Men in the Sun and its significance and the deep meaning behind the literal meaning of these symbols. The study tries to examine the basic symbol of the story "the walls of the tank are not pounded", as these three men die suffocating in the tank, without any of them daring to knock the walls of the tank for help. The symbolism of the non-knocking of the walls indicates the legitimate cry of the Palestinian people conflict, who have suffered from displacement. Other symbols in the novel are also analyzed to show how the writer used them for artistic and political purposes.
\end{abstract}

Index Terms-symbolism, MEN IN THE SUN, displacement, Palestinian people, Kanafani

\section{INTRODUCTION}

A literary symbol is simply defined as a word, a character, a thing, or situation with references beyond its literal meaning. It can be a character, a thing, an event, a word or a group of words. It refers also to the actions of a character that have a deeper meaning in the context of the whole story. "Symbolism" is originally derived from the word "symbol" which derives from the Latin word "symbolum". Symbolum in Latin means a symbol of faith or a sign of recognition. Cuddon (1998) defines symbols as following. - The word symbol derives from the Greek verb - symballeinll, — to throw togetherl, and its noun — symbolon\|, — markll or - signll. It is an object, animate or inanimate, which represents or stands for something else. Wikipedia defines symbol as "something that represents, stands for or suggests an idea, belief, action, or entity" Symbolism is important in literature in general and the novel in particular. It is used when one thing is meant to represent something else or to convey a meaning, which is deeper and more significant than the surface meaning. Symbolism helps create meaning and emotion in a story and bestows more depth to the literary work.

Men in the Sun is Kanafani's master piece in which he follows Abu Qays, a Palestinian refugee from Yafa and his friends as they try to make it to the oil fields of Kuwait for work. Facing miles of desert long arduous journey under the scorching sun, the three men end up slowly suffocating to death in the back of a water tank truck. Ironically, they do not attempt to save themselves by banging or knocking on the walls of the tank. The novel is an allegory of the Palestinian plight and a sharp criticism the Arab leaders' silence on the Palestinian issue. It is a story of human suffering and tragedy that ends in a different sort of suffering and tragedy. Not a lot happens in the story, as the action is as much internal as external. The four central characters are burdened with the desire to escape the past so dreaming and remembering preoccupy them. Their journey is one from the past to the future that never comes. Their present is anxiety and frustration. When they manage, at last to get on the road to Kuwait they are fated to die before reaching their destination.

The novel can be read at different levels. "On one level it can be read as an exposé of (the main characters') weakness in preferring the search for material security over the fight to regain their land, and also as an attack on the corruption of the Arab regimes that allowed them to suffocate in an airless, marginal world of refugee camps."(Essays" being a political novel, Men in the Sun is full of symbolism. What characterizes its symbolism is that it is an integrated part of the text and not imposed upon it. The sun, the water tank, and even the four main characters are all symbols that can represent different things. The ending of the story has also symbolic significance. Studying the various aspects of symbolism in the novel will yield fruitful results in terms of the real messages of the writers and his intentions in writing the novel. 


\section{STATEMENT OF THE PROBLEM}

Symbolism is an integral part of the literary expression and human expression in general. From times immemorial, humans have been using different symbols to communicate among themselves. In literature, symbolism is a very important literary device used by writers to give their literary works an artistic beauty and depth. Writers can also use symbolism to criticize society behind those symbols and avoid troubles and problems that may fall upon them as a result of that criticism. Kanafani is a novelist who used symbolism extensively in his novels. His novels cannot be fully understood without analyzing their symbolic structure. This study is an attempt to examine the symbolism in Men in the Sun and its significance and the deep meaning behind the literal meaning of these symbols.

\section{AIMS OF THE STUDY}

The study aims to answer the following questions:

Why did Ghassan Kanafani use symbolism in his novel and how did he use it?

What are the symbols he used? Was he successful in employing symbolism for artistic purposes?

How Kanafani portrayed the suffering of the Palestinians through different types of symbols?

How did he use the main Symbolic Dimensions (Tank, Desert, and Death)

\section{LITERATURE REVIEW}

The core of this paper is viewing social life symbolically in one of the greatest novel written by Kanafani that is Men in the Sun. Before going deeply into analyzing the novel let's introduce symbolism as an expressive tool in literature. Symbolism is a special rhetoric technique that helps the writer to 'present' a concept too abstract or obscure for direct sensory representation, that can be expressed only "by analogy and by the transference of reflection" (Kant 1951, p. 198). ${ }^{1}$

According to Collins Dictionary, a symbol is « An object, person, idea, etc. used in a literary work, film, etc., to stand for or suggest something else ». ${ }^{2}$ Edward Quinn (2006:408) states that "Referring to the process by which a person, place, object, or event comes to stand for some abstract idea or condition. As normally used in literary study, symbol suggests a connection between the ordinary sense of reality and a moral or spiritual order."3

Symbolism is generally an object representing another or giving it a totally different meaning which is more significant and deeper than the literal meaning. In a symbol, fundamental relation of form and content is "intrinsic" based on the conventional meaning and additional specific connotations; "it implies something more than its obvious and immediate meaning" (Jung 1964, p. 21). ${ }^{4}$

In literature, symbolism occurs when a writer uses an object, a person or a situation to add an inner and deeper meaning to the text. In novels, novelists use symbolism as a literary device not only for artistic reasons but also for political ones. Some novelists use it to avoid being persecuted by the political regimes in non-democratic countries. Symbolism gives them more scope and freedom to express their thoughts in an indirect way. According to Chris Baldick, literary language employs symbol as "a specifically evocative kind of image, a word or a phrase referring to a concrete object, scene, or action which also has some further significance associated with it" (1990, pp. 218-219)..$^{\circ}$

The symbolic trend in literature was associated with a school of French poets around the mid-19th century, including Baudelaire, Malarme and Verlaine. It is a new method of expression, which focuses on highlighting psychological situations and acute emotions, and adopts the suggestion instead of the report, and the symbolic poets rejected the traditional methods in poetry systems, so they stressed the ambiguity to shift the mind of the reader from reality to reality beyond the essence of the idea and its actual reflections receiver. The symbolism then moved from poetry to novel and play, and the first was initiated by the novelist (Henry James) who called for the need to develop the traditional mold of the novel, from interest in external events to internal events, ie (to the circle of self). Langer thinks, in his philosophy, that symbols are interpolated in the "gaps and confusions of direct experience" (Langer 1954, p 22). ${ }^{6}$

Goethe and Carl Jung stress that symbols' function is to explicate "something vague, unknown, or hidden from us" (Jung 1964, p. 21) ${ }^{7}$ or "reveal the inscrutable" (Goethe 1973, p. 471). ${ }^{8}$ He also called for renewal in the traditional plot and turned it into a (technic) depends on tracking the course of human feeling and materialization through the stream of consciousness. The stream of consciousness, or the so-called (internal dialogue) or (monologue), has attracted the interest of novelists. They also believe that it is better able to uncover the essence of man and explain his external actions, a new technique used by the symbolists to highlight the psychological states of the subconscious in man. Kant

\footnotetext{
${ }^{1}$ KANT, I., 1951 Critique of Judgment. New York: Hafner Press.

${ }^{2}$ Collins. ( 2014) "symbol." Collinsdictionary.com.

${ }^{3}$ Quninn, Edward. (2006) .A Dictionary of Literary and Thematic Terms. New York: Infobase

${ }^{4}$ JUNG, C., 1964. Man and his symbols. New York: Anchor Press book.

${ }^{5}$ Baldick, C. (1990). The Concise Oxford Dictionary of Literary Terms. Oxford: Oxford UP.

${ }^{6}$ LANGER, S., 1954. Philosophy in a New Key. New York: The New American Library.

7 JUNG, C., 1964. Man and his symbols. New York: Anchor Press book.

8 GOETHE, J. W., 1973. Werke, Hamburger Ausgabe, Munich: C.H. Beck, vol. 12.
} 
and C. Jung refer symbols to the area of the unconscious. Kant defines the symbol as a form of hypotyposis ${ }^{2}$ a rhetorical mode involving presentation or illustration; he postulates that Symbol is an Idea of imagination which is greater than the mere concept of rational thinking and understanding. It induces much thought, "yet without the possibility of forming any definite concept adequate to it," and a symbol cannot be made completely intelligible by language. It is within the scope of creative imagination that "unbounded expansion" to the concept is possible, an extension of thought that exceeds what can be clearly expressed by logic (Kant 1951, pp. 175-177). ${ }^{9}$ It has become the event in the modern novel presented from this area (the subconscious area) any consideration from within the character and how it relates to the event and its impact.

The symbolic novel does not offer real traditional characters as much as human models characterized by the burning mind and suffering, as it is in constant conflict with itself and with the outside world, the writer presents these feelings through the course of the feeling of his hero, while the other character's support and help to highlight. Symbolic novel requires a special language (or special dealing with language) which lies in expressing the complex psychological atmosphere, and depends on the suggestion, it is closer to the scattered hair because of the suggestive charge to express complex psychological situations. It is worth mentioning that researchers insist that the ability to produce symbols is the sole prerogative of human beings who can "bestow meaning upon things and events in the external world, and comprehend such meanings" (White 1973, p.1). ${ }^{10}$

We conclude that the symbolism in the novel depends on the (stream of consciousness), introspection within the personality and psychological and emotional analysis, and painted as human models, and highlight the impact of events on the personality, in addition to suggestive language.

\section{SYMBOLISM IN MEN IN THE SUN}

In his novel Men in the Sun, Ghassan Kanafani proves that creativity has a rich record of different visions and ideologies, which the writer can highlight through his qualitative product, which the individual receives in support or dissent. Kanafani sought to highlight the features of his own thought through the contradictory psychological models that convey our actions, reminding us of the many problems corresponding to the repercussions of our contemporary political life.

Perhaps "men in the sun" is a social document full of many intellectual contradictions and sentimental dichotomies. The title itself refers to a paradoxical symbolism. The word "men" tells us to make us imagine heroes representing the violence and the essence of manhood, while their actions disappointed us, and even hit the extent of their defeat and dispersal. The word "sun", which overwhelms us with its light and shine, and gives us a glimmer of life once its name is spoken, becomes a fatal tool in the novel and a source of concern and condemnation.

The men, who spend their lives in a dry cistern under the scorching sun, are the heroes of this tragic novel, driven by their paradoxical psychology to execute death par excellence, justifying their condemnation of the reality of living, distraction and humiliation, and the result that their corpses in Kuwait were almost as an accessible paradise.

Kanafani portrayed the suffering of the Palestinians, who were deprived of the right to a dignified life after being afflicted, represented by the story of three Palestinians representing different generations of age, who were disguised by the world and people. They sought a distant hope, or a simple dream, for which they paid their lives.

This novel is a symbolic framework for multiple relations centered on the Palestinian death and the need to get out of it towards the discovery of the historical act, or search for this act, in which he condemns the cases of individual salvation untied to the masses, because it is doomed to failure and death in a desert without life, after they were stranded as a clear consequence of the occupation, and for those who decided to flee to countries other than their own to run behind the mirage.

The heroes of the story are: Abu Qais; As'ad; Marwan; each has his own problem, in addition to the problem of the homeland. Abu Qais is far from his wife and children. As'ad puts his possibility that he may not reach Kuwait, as well as Marwan, they decided not to pay the smuggling fee until they reach their target.

Their lives were almost impossible in the refugee camps, so they had to leave the camp in search of a living and happiness in another country. The three met in Basra to travel to Kuwait by smuggling. In Basra, they met a Palestinian named Abual-Khizuran, a freshwater truck driver in Kuwait. They agreed with him to smuggle them for a few dinars each, and they actually went up next to the driver at the beginning of the road. When they reached the Iraqi border checkpoint, they moved into the empty tank of water, until the driver completed his travelling documents and then returned to sit next to him to continue their journey to the unknown.

When they arrived at the Kuwaiti border, they went back into the tank, where it was dark and hot, but it took longer than the usual seven minutes to seal the travelling documents. Kuwaiti soldiers joked with the driver, and it took about twenty minutes, enough to turn them into dead bodies. He then threw them near a rubbish dump in the desert, having robbed them of what they had with them. "Why didn't you knock the walls of the tank?"

This question, which concluded the story calls for answers not provided by the text, a new conclusion of the novel.

9 KANT, I., 1951 Critique of Judgment. New York: Hafner Press.

10 WHITE, L., 1973. The Concept of Culture. New York: Burgess Pub. Co. 
The story represents a realistic symbolism, not without the romanticism by which the writer presents the cry of his people, which bears a history before the Palestinian Nakba had started in 1948. Realism and dialectical discourse lead us to stand on the reality of progressive realism and revolutionary approach, which is adopted by the writer (the realistic approach).

The novel revolves around two ideas: emotion in its dimensions: psychological, social and struggle, on the one hand, and the title of identity and entity on the other. Kanafani succeeded in employing these two elements profoundly characterized by a transparent human spirit, and in romantic templates that do not lose their sense of realism.

Romanticism has been accompanied by the currents of Palestinian literature and trends developed in the story of "Men in the Sun" despite the tyranny of some other currents, romance is emerging, especially in the first part of the story, due to the real causes in the Palestinian cause, as a result of the difficult conditions prevailing after being afflicted. As a result of the human rights of the refugees in the Diaspora, which led Kanafani to express the attempt to rid his heroes, probing their thoughts, and unveiling their internal pain, and displaying it directly in order to draw a life for a better future, where security and stability ... and the assertion of the Palestinian human right to dream of his land.

There are symbolic revelations or connotations of the story, but they do not tend to drown in symbolic images, as it can be called "real symbolism", as the three story heroes (Abu Qais, As'ad, and Marwan) symbolize the entire Palestinian people, Abu al-Khizuran symbolizes the failed, defeated leadership, and the smuggler Al-Basrawi symbolizes human exploitation in the most heinous form, and customs officials symbolize the Arab official and the corrupt bureaucracy. The Sahara symbolizes the space between life and death. The tank symbolizes siege, imprisonment, grave and death, and death symbolizes escape to a new life.

Kanafani resorted to making the image intensive as a function of the journey of torment as embodied in the desert and tank. These two symbols together and in their interaction create a highly effective artistic image ... It also contributed to the success of this image as a Palestinian image, and that all the characters in which the novel dates their lives and they also represent and symbolize the entire segments of the Palestinian people.

The image intensifies in the character of Abu al-Khizuran, for example, he is an old Mujahid who lost his manhood and homeland became a victim, but he turned into a big rat looking for his victims. If he did not eat he would be eliminated, so he is the leader of the journey of destruction, he is a leadership that does not fulfill his promises and responsibilities therefore, we pity him as much as we condemn and reject him.

In a final reference to the narrator in "Men in the Sun," he seems to know everything. It is the narrator who is present with his characters wherever they traveled The places where the narrator appears as a narrator indicate that he is familiar with everything.

\section{The Symbolic Dimensions (TANK, Desert, DeATH)}

\section{A. The Tank}

Kanafani employed the water tank in a clear irony. Water is the main element of life, but in this novel he deliberately made the tank empty of water, as if it were empty of life. His account showed that the tank did not carry water for a long time.

He made the tank used in the wrong purpose, that is, when it does not carry water, it carries death, and writer did not make the (Abu al-Khizuran) deceptive in this regard, as he told the three men the truth of what is waiting for them in the tank, although he tried to lighten it a little when he preached that the heat is suffocating and frightening here, and you will sweat as if you are in the fry, but for five or seven minutes, I will drive as fast as I can."

The tank was therefore a symbol of the siege and imprisonment for the Palestinian people who are guided towards with their corrupt Arab leadership, which the writer in the novel symbolizes as the driver who leads the tank to death (Abu al-Khizuran). The tank is the image of hell and the height of the tragedy of the Palestinians, the great prison they have to destroy if they want to survive.

Access to the tank has a profound significance, making the writer a reason to condemn his heroes, but also to reduce the element of surprise to the recipient. In the novel, in the first access to be inside the tank, the tragic act that paves the way for the tragic end of the heroes, even though the men first came out with faces resembling "mummified yellow faces" and although they realized that their way was fraught with death, from the seriousness of what they accept, they did not hesitate to go down to the tank again and face their fate with submission.

The moment of the death of the three heroes did not seem surprising in this novel, because of the previous experience of the first incomplete death in the first access, as well as many elements of the foresight placed by the writer on the tongues of all personalities to express their fear of the fate of the unknown inevitable, including the words of Abu Qais "It is an unsafe adventure," he said. "Do you guarantee that we will arrive safely?"

In this context, the question arises: Why did the author not let his three heroes die in their first entry into the tank? In his artistic construction, he may have deepened the tragic dimension of the novel. "It is the tragic hero who chooses ... and his fate is determined as an inevitable consequence of this choice. The tragedy of the modern Arab hero is the tragedy of his choice, because he has no control over it."

The writer intended to condemn the personalities for their complete surrender to this death. He did not want to have a great emotional impact on them. He wanted us to denounce their foolishness and their passive surrender. He wanted to address our minds to convict these men, and there is an important symbol that the three men are the equivalent narrators 
of the Palestinian people who died without a grave, or died according to the novel in the tomb of the tank.

\section{B. The Desert}

Hilary Kilpatrick reads the symbolism of the desert, stating that it "represents the ordeal of fire that the Palestinians must pass through, and it is depicted in its starkest guise; its presence contributes to the suspense that is built up as the lorry races along under the boiling August sun" (1999, p.12). In fact, the desert as a literary symbol can signify "freedom of soul and being naked" while fire "is a symbol of purity" (Fadaee, 2011, p.20. ${ }^{11}$

The characters of the three men in the novel "Men in the Sun" have reached a great deal of despair, with whom they are no longer able to fight for any hope on the horizon, but they have been captive of the past - in which they see the happiness that has gone forever - they no longer have the ability to change the dark present, each resorted to individual salvation, which is the paradise they sought on their journey to Kuwait.

Unfortunately, these men were so desperate that they could not choose the right path. They chose the route to escape, and they were unable to choose the right leader to lead them on their journey. They chose a helpless man. This man, who is incomplete. Can he lead them to their destination peacefully?

The writer presented forward-looking models of the fate that may lead them to the desert road, including what had been said by As'ad more than once: "The road. There are still ways in this world did not wipe it with his forehead and washed his sweat for days and days." As'ad was wary of not reaching Kuwait, therefore, insists not to pay the fat man or the Basrian smuggler until after arrival, and perhaps this was the consciousness that was formed with him because of his trip from Amman to Basra, where Abu al-Abed proved him to be a thief, which made him expect that the smuggler would not be better than him.

Perhaps what made the image of the desert and its fear of the unknown and human suffering with extreme heat become closer to us as recipients, is the accuracy of the narrator's description of the desert in As'ad's first voyage "The sun was pouring a flame over his head. He passed through a solid bottom of a cliff." You see them if they carried me to the desert Jafr prison, would it be more merciful than it is now?

What makes the horror lies in the As'ad' thinking towards the desert that it is full of rats "Of, this desert is full of rats, you see what they eat? ... Rats smaller than them" As if the author intended to symbolize these rats - which the large feed on the small - to humans those who eat the big ones on the little ones, but be careful not to eat the rats before you travel, as if to say to As'ad: watch out, little rat, the big rats will eat you, and he must have meant those (Abu al-Abed), the fat Basrian man, and the Abual-Khizuran and the like.

However, As'ad insisted that he will surrender to this fate, even the hotel, which was supposed to be a place of rest and tranquility, was full of rats, and the guilt was not the guilt of Abual-Khizuran, because he did not hide the brutality of the men of the desert. He said: "These 150 kilometers to me like the path that God has promised to create before people are distributed between Paradise or Hell. Whoever fell from the path went to the fire, and who passed it reached paradise". His laughter was a mockery of a demon with these idiots.

Talking between As'ad and Abu al-Khizuran during the trip, the latter reinforces the idea that the big rats feed on the small when he tells the stories of smugglers who always give up who wants to reach Kuwait, and is lost and forced to buy a sip of water from the desert nomads with all his money and valuables. In one or two pages, Abu al-Khizuran mastered the brutality of the desert and the horror of the desert. Kanafani returned to confirm the predatory nature of the desert. Here, the desert itself becomes a big rat that feeds on small rats. So the external reality - represented by the desert - is predatory.

So the desert becomes the space between life and death, a symbol of the political vacuum and the endless journey of torment without the possibility of reaching the desired goal. The Sahara represents the tragedy of the Palestinian person, which is spreading throughout its dispersal and displacement

\section{Death}

The writer ended the lives of his characters in this novel by death, but did not let them die in the battlefield, or in the case of someone defending himself or his land or honor, and perhaps the author has intended to deepen the level of condemnation of the defeatism of his heroes in this novel, as he chose them to die dishonestly.

The moment of death in this novel was not logical. Logic presupposes that men should knock on the walls of the tank when they feel suffocated, and the result is death afterwards, although the act of knocking the tank may lead to survival or death, then they have exceeded the inevitability of death to the possibility If they die then they will die as real men.

But the moment that puts us in the face of bereavement is the moment of getting rid of the bodies of the dead (the three men), Abu Al-Khizuran did not take the minimum effort to keep up with the bodies of the three men but was as selfish as it was from the beginning, and only thought of his fatigue ... Now he feels tired and eroded, as if his arms were injected with an anesthetic, with no energy to work, and he would not be able to hold the shelf for long hours to dig three graves.

He is thinking of doing something up normal! He chose for his three comrades the worst, most vulgar and

11 Kilpatrick, H. (1999).“Introduction.” In Men in the Sun and Other Palestinian Stories. Ghassan Kanafani., 9-15, Colorado: Lynne Rienner Publishers, Inc. 
disrespectful fate of their humanity, and chose to dump them in the landfill and to satisfy his conscience he tried to convince himself that the government would oversee the burial of the bodies themselves when they discovered them in the morning. Now, he is thinking loudly: If the bodies were thrown here, they would be discovered in the morning and buried under the supervision of the government ... Lifting the body from the legs and throwing it up and hearing its thick voice rolling over the edge of the tank, and then the sound of its impact strangled on the sand, it was very difficult to unscrew the other body from the iron bar., And then pulled from its legs and threw it from above shoulders.. Straight convulsive and heard the sound of hitting the ground. The third body was easier than the other two...

In this novel, the writer intended to conclude with the death of the heroes, a free death at the end, the death they deserve in his opinion, because they were passive from the beginning, and surrendered to the unknown fate that they felt was fraught with danger, especially after they tried to go down in the tank the first time. To exacerbate his condemnation of his heroes when Abual-Khizuran made their leader on this journey dump their bodies in the landfill, as well as that they were thrown into the dustbin of history, the place they deserve, the author then chose for his characters free and cowardly death instead of choosing them honorable death. This is evident in his attitude towards such personalities who chose individual salvation and surrendered themselves to an uncertain leadership and an unknown destiny. There is a tragic turn because the hero dies convicted, although he could die unconvicted. Therefore, this incident becomes appalling and reprehensible.

Kanafani does not only suffer from the tragic and humiliating end of his heroes, but he tries to make Abu al-Khizuran (their leader in the journey of death) completely dehumanizes them. The tragic characters, when he stole their valuables, "but he soon alerted to something after he went a long way, and turned off the engine of his car again, and returned to where he left the bodies, took the money out of their pockets, and took away Marwan's clock and returned to the car walking on the edges of his shoes. "

\section{CONCLUSION}

The novel of MEN IN THE SUN is one of the first novels by Ghassan Kanafani, the most important and most prominent, was published in 1963. The main theme of the novel is homelessness and death. It reflects the Palestinian cause, the 1948 catastrophe and its impact on the Palestinian people through four Palestinian men of different generations who tell their story in a wonderful symbolic way. When reading the novel of MEN IN THE SUN, you cannot skip one line in this novel without finding a symbol for each word which refers to the conditions of the Palestinians after the catastrophe (Nakba) in 1948. The novelist reflected the issue through the characters, as each character in the novel symbolizes a certain personality of his people. The story is the story of three men who decide to emigrate from Palestine to Kuwait illegally for their desire to improve their living conditions. Another man, 'AbualKhizuran, who suggests to transport them in his truck, which they must hide in its tank until they reach the border points. The novel ends with the death of the three men suffocating for fear of beating the walls of the tank. In the novel, there are four main characters, the first character, the character of Abual-Khizuran, the smuggler who was offered to the three men to transport along the Iraqi-Kuwaiti border for a sum of money. As for the three men, the first person is Abu Qais, an old man of old age, who decided to emigrate to earn a living for himself and his children, to get the money to buy olive trees rather than lost. The second character is the character of As'ad, a political person and a fighter fleeing the country to get more freedom, the character of the Palestinian pursuer. The third character is Marwan, the sole breadwinner of his family, who decides to emigrate to escape his responsibility. Kanafani focuses in the use of rhetoric crowded with symbols, and we said that the symbolic novel uses condensed abbreviated and suggestive language as a poem.

The Novel (MEN IN THE SUN) where there is no redundant word or position without meaning or phrase construction, and does not resort to Kanafani slogans or report and direct, it uses metaphoric language excellently, every word suggests something. Kanafani's use of this suggestive language aims at two things:

First, technically, art is a suggestion, not a report, and the language in which it describes characters and events suggests to us the meanings it does not decide directly, but we realize that it. Secondly, it connects the personality and the event with this suggestive language to increase its depth, clarity or suffering, and increase the visibility of the event, and the distant meaning that the writer aims at when he recounts an event in a symbolic suggestive way.

When Abu Qais lay, for example, on the shore of the Shatt al-Arab in Basra, he looked at the sky and it was glowing white (see novel, p. 8) and the black bird continues to follow Abu Qais. (the sound of the Shat wasters, the sailors shout, the sky glows and the black bird Still hovering adrift) (the novel, p. 14) ${ }^{12}$ It is the suffering he carries within him, chasing him, worry him from the unknown, walking with him adrift like that bird.

The black baths hunt down Marwan, he saw them when he got up early to meet Abu al-khizuran .. (The sky still looks blue in which black baths hover at low altitude and hear shelves wings as they approached in its vast sky over the hotel) (novel, p. 36) ${ }^{13}$ It is death that awaits him.

The word of the road, which the fatty Iraqi smuggler insists to tell As'ad in Basra .. (you can turn around and take

12 Men in the Sun, Ghassan Kanafani, Dar Triangle for Design, Printing and Publishing, i 10, 2011.

13 Men in the Sun, Ghassan Kanafani, Dar Triangle for Design, Printing and Publishing, i 10, 2011. 
three steps and you will find yourself in the way) (novel, p. 20), the road is the same road that he walked for hours between the sand and rocks in the desert between Jordan and Iraq alone after the Palestinian smuggler deceived him, the same road he would take in the hope of reaching Kuwait, and he dies on the side of the road.

And another symbolic picture when the wife of the foreigner - who took As'ad in his car and brought him to Baghdad .. (Off! This desert is full of rats, you see what they eat? He answered quietly: rats smaller than them ..) (novel, p. 29), a symbolic image reflects as they are, they are easy hunting for those who are bigger (smugglers) for them, and in general is the tragedy of the Palestinian people. (The symbols are many in the novel)

Another technique used by Kanafani in the novel, a method of paradox to highlight the magnitude of suffering, such as the joking of the border men to Abu al-Khizuran, causing him to lag behind the bottom of the tank until they died. Another paradox is that when a man who has lost manhood is accused of having relations with women, the border men claimed that Abu Khizuran had a business. (See Novel, pp. 87-85). ${ }^{14}$

Final point, when Abu al-Khizuran threw the three bodies in the dustbin, stripped them of money and hours, he drove away, wondering:

- Why didn't you hammer the walls of the tank ...?

- Why didn't you knock the walls of the tank? Why didn't you say? Why? And suddenly it started

The whole desert echo frequency:

- Why did not knock the walls of the tank?? Why? Why? Why? (Novel, p. 95). ${ }^{15}$

It is the cry that Ghassan Kanafani launched, and ended his novel, by the words of Abu Al-Khizuran first and then echoed by the desert. This position or end has two meanings. The first is for Abu Al-Khizuran as for the voice of the desert, which carries the truth and history: Why do Palestinians die haphazardly? Why? Why? This cry (why didn't you knock the walls of the tank?) opened the door of great hope. Men in the Sun are coming, they will not need the chariot of death, because they will know the way to the sun of real life, an optimistic connotation that Kanafani exemplified in his later novels (What is left for you). Guerilla, and (returning to Haifa) where the Palestinian rebel.

Finally, the main symbolism of the story of MEN IN THE SUN, is that the walls of the tank are not ringing as these three men die of suffocation in the tank, without any of them daring to knock the walls of the tank for help, and the symbolism of not ringing the walls refers to the legitimate screaming of the Palestinian people who have been displaced.

\section{REFERENCES}

[1] Baldick, C. (1990). The Concise Oxford Dictionary of Literary Terms. Oxford: Oxford UP.

[2] Collins. (2014). "symbol." Collinsdictionary.com.

[3] Cuddon, J.A. (1998). The Penguin Dictionary of Literary Terms and Literary Theory. England: Penguin Books.

[4] Essays, UK. (2018). The Men in The Sun Story English Literature Essay. Retrieved from https://www.ukessays.com/essays/english-literature/the-men-in-the-sun-story-english-literature-essay.php? retrieved time $29 / 8 / 2019$.

[5] GOETHE, J. W. (1973). Werke, Hamburger Ausgabe, Munich: C.H. Beck, vol. 12.

[6] JUNG, C. (1964). Man and his symbols. New York: Anchor Press book.

[7] KANT, I. (1951). Critique of Judgment. New York: Hafner Press.

[8] Kilpatrick, H. (1999). "Introduction." In Men in the Sun and Other Palestinian Stories. Ghassan Kanafani., 9-15, Colorado: Lynne Rienner Publishers, Inc.

[9] LANGER, S. (1954). Philosophy in a New Key. New York: The New American Library.

[10] Kanafani, Ghassan. (2011). Men in the Sun, Dar Triangle for Design, Printing and Publishing, i 10,

[11] Quninn, Edward. (2006). A Dictionary of Literary and Thematic Terms. New York: Infobase

[12] WHITE, L. (1973). The Concept of Culture. New York: Burgess Pub. Co.

Omer Hago Elmahdi currently works at the Department of Languages \& Translation, Taibah University. Omer does research in Linguistics, Media, Teaching Methods, Teacher Education and Pedagogic Theory.

Abdulrahman Mokbel Mahyoub Hezam is associate professor of literature at Faculty of Arts, Taiz University, Yemen. He currently works as head of the Department of Languages \& Translation, Taibah University, Al-Ula, KSA. 